\title{
Research of nanoscale titanium carbides influence on the structure and properties of weld metal in automatic submerged arc welding
}

\author{
Nikolay V. Kobernik ${ }^{*}$, and Alexander S. Pankratov \\ "Welding and Testing" of MSTU n.a. Bauman, 105005 Moscow, Russia
}

\begin{abstract}
The influence of nanoscale refractory titanium carbide particles on the structure and properties of weld metal in automatic submerged arc welding is considered. Composite granules based on nickel were used to introduce the compound into the composition of the weld pool. Two schemes for introducing granules into the weld pool were tested, characterized by different temperature conditions: to the head part of the welding pool with the help of "ligature" and to the tail section with the help of additional filler wire. The prospects of introducing nano-sized titanium carbide into the tail part of the weld pool as part of a flux-cored wire are shown. With this method, the structure of the weld metal is observed to modify: the average size of the primary crystals of the weld metal is reduced by almost $50 \%$. At the same time, the value of the toughness of the weld metal increases: the average value of this index increases by $36 \%$. When titanium carbide is introduced as part of the "ligature" into the head of the weld pool, despite the effect of modifying (reducing the width of the primary crystals by $30 \%$ ), the average value of the toughness of the weld metal decreases.
\end{abstract}

\section{Introduction}

Submerged arc welding is widely used for fabricating metal structures from low carbon low-alloy steels. Also, there is a wide application of multi-arc submerged arc welding (SAW) processes, which help to significantly increase the productivity of the process [1]. However, increased heat input in this case leads to the formation of coarse structure of the weld metal, which reduces its plastic characteristics.

Usually, to improve the plastic characteristics of the weld metal, the alloying elements that make up the welding materials are selected, and also various technological methods are used. Recently [2], the approach of modifying the weld metal with nanoscale particles has been widely developed, when impurities and additives are used to achieve grinding of weld metal, which contributes to the improvement of its mechanical properties, and, in particular, to an increase in the toughness.

The work carried out earlier by the authors was directed to the introduction of such refractory nanoscale compounds in a welding pool during submerged arc welding, such as tungsten carbide and titanium nitride, according to different schemes: to the head part of the

* Corresponding author: koberniknv@bmstu.ru 
weldpool with the help of "ligature" [3,4] and to the tail part with the aid of filler wire $[5,6]$. In this case, the ligature was a composite pellet based on nickel (PNE-1 according to [7]), mixed with nanoscale particles in a planetary mill in a ratio of $70 \mathrm{wt} \%$ nickel and 30 wt $\%$ nanoparticles. The same composite pellets were added to the composition of the charge of a specially developed flux-cored wire that was fed to the tail section of the weld pool and further heated by an electric current passing through it to stabilize the feeding process. As a result of the work, the positive effect of the introduction of tungsten carbide was shown in different schemes: when introduced through ligatures, it provides an increase in the values of the toughness, and with the help of flux cored wire the stabilization of the values. Titanium nitride also improves the mechanical characteristics of the weld, but its dissociation leads to pore formation.

Such a compound as titanium carbide can also be effective as a modifier, but for this it is necessary to study its effect on the structure and properties of the weld metal, including, depending on the method of introduction.

Therefore, the purpose of this article is to establish the degree of influence on the structure and properties of the weld metal of nanoscale titanium carbide particles introduced into the weld pool using a ligature and a flux cored wire.

\section{Experimental}

Experimental studies were conducted according to two schemes:

- Two-arc SAW with a pre-laid "ligature";

- Single-arc SAW with the addition of additional flux cored wire fed to the tail of the weld pool - welding with a supplemental hot additive (SHA).

Samples for welding were made of St3sp according to [8]. Sample dimensions: 300x100x10 mm (LxWxS) for two-arc welding and 300x100x8 mm (LxWxS) for singlearc welding with SHA. Type of welded joint - according to [9] (with permanent backing) for two-arc welding and C-5 according to [9] (with permanent backing) for welding with SHA. The types of cutting used make it possible to weld in one pass, and the permanent backing does not require special measures to prevent burns and formation of the back side of the seam. In addition, in the welding version with "ligature" dulling allows you to control the dosage of the introduced "ligature", and the steel lining will keep it from rash.

The combination of an electrode wire and a welding flux is selected for reasons of a welded joint in one pass, with a chemical composition of the weld metal of $0.08 \% \mathrm{C}, 1.7 \%$ $\mathrm{Mn}, 0.9 \% \mathrm{Si}$, less than $0.025 \% \mathrm{~S}$, and less than $0.03 \% \mathrm{P}$.

"Ligature" was made by mixing nickel powders (PNE-1 according to [7]) with an average size of at least 50 microns and nano-sized particles in a proportion of $30 \mathrm{wt}$. \% nanoparticles and $70 \mathrm{wt}$ \% nickel. Nanopowder of titanium carbide was obtained by the method of plasma-chemical synthesis in thermal plasma using an electric arc plasma torch $[10,11]$. The powder consists of individual, non-porous particles of equiaxed shape. The average particle size of titanium carbide is $50-60 \mathrm{~nm}$. Powders are characterized by a particle size distribution close to logarithmically normal [12] and single-phase. The resulting conglomerate is called a composite granule. The same composite granules were introduced in an amount of $2.5 \%$ by weight to the cored wire of the flux cored wire. The filling ratio of the cored wire was $25 \%$. The diameter of the flux-cored wire is $2.0 \mathrm{~mm}$. The wires were manufactured in OOO "NIIMontazh".

To perform the experiments, the parameters of the regime were selected that ensure the formation of the selected welded joint in one pass (Table 1 and Table 2). 
Table 1. Parameters of the regime used in studies of two-arc submerged arc welding with the use of "ligature"

\begin{tabular}{|c|c|c|c|}
\hline \multirow{2}{*}{ № } & \multirow{2}{*}{ Parametres } & \multicolumn{2}{|c|}{ Диапазон значений } \\
\hline & & First arc & Second arc \\
\hline 1 & Current type & $\mathrm{DC}+$ & $\mathrm{AC}$ \\
\hline 2 & Current intensity on each arc, $\mathrm{A}$ & 650 & 650 \\
\hline 3 & Voltage, V & 27 & 32 \\
\hline 4 & Welding speed, $\mathrm{m} / \mathrm{h}$ & \multicolumn{2}{|c|}{45} \\
\hline 5 & Electrode stick-out, $\mathrm{mm}$ & 30 & 40 \\
\hline 6 & Distance between elecrodes, $\mathrm{mm}$ & \multicolumn{2}{|c|}{27} \\
\hline 7 & Electrode tilt angle & $90^{\circ}$ & $\begin{array}{c}60^{\circ} \text { (forward } \\
\text { angle) }\end{array}$ \\
\hline 8 & Balance, \% & 100 & 25 \\
\hline \multicolumn{4}{|c|}{$\begin{array}{l}\text { Note: } \\
\text { DC+ - direct current reverse polarity; } \\
\text { AC - alternating current; } \\
\text { Balance is the ratio of the arc burning time at the reverse polarity to the duration of the arc burning } \\
\text { period. }\end{array}$} \\
\hline
\end{tabular}

Table 2. Flux welding conditions with supplemental hot additive

\begin{tabular}{|l|c|c|c|c|}
\hline Run & \multicolumn{2}{|c|}{ Run $\langle\mathrm{A} »$} & \multicolumn{2}{c|}{ Run «B» } \\
\hline Wire & Main & SHA & Main & SHA \\
\hline Current intensity I, A & 750 & 200 & 650 & 300 \\
\hline Current type* & DC+ & AC & DC+ & AC \\
\hline Voltage U, V & 34 & $<12$ & 32 & $<12$ \\
\hline Wire feed speed $\mathrm{V}, \mathrm{m} / \mathrm{min}$ & - & 5,4 & - & 11,2 \\
\hline wire size d, mm & 4 & 2 & 4 & 2 \\
\hline Electrode stick-out, $\mathrm{mm}$ & 35 & 50 & 35 & 50 \\
\hline Welding speed $\mathrm{V}_{\mathrm{w}} \mathrm{m} / \mathrm{h}$ & \multicolumn{5}{|l|}{45} \\
\hline Percentage in weld metal, \% & 16 & & 41 \\
\hline *DC+ - direct current reverse polarity; \\
AC - alternating current
\end{tabular}

The "ligature" was previously laid in a cut with a height control of the backfill (Figure 1). Two variants of backfill in height were tested: 2 and $3 \mathrm{~mm}$. As a result, compounds were obtained, characterized by the number of introduced nano-sized particles in accordance with Table 3. Also, to determine the degree of influence of nano-sized particles on weld metal, experiments were performed on welding with filling of nickel powder (PNE-1 according to [7]), introduction of wires, The charge of which was injected with nickel powder (PNE-1 according to [7]), as well as a variant without additional additive, the so-called "basic version".

\section{"Ligature"}

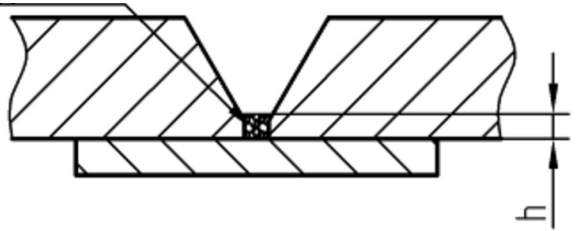

Fig. 1. Control of the height of the ligature: $\mathrm{h}$ - controlled filling height 
Table 3. Tested versions of the welds. Research and test results

\begin{tabular}{|c|c|c|c|c|c|c|c|c|c|c|}
\hline $\begin{array}{l}\text { Process } \\
\text { scheme }\end{array}$ & $\begin{array}{c}\text { Condition } \\
\text { (run) }\end{array}$ & $\begin{array}{c}\text { Filler } \\
\text { material } \\
\text { mark }\end{array}$ & $K_{n}, \mathbf{w t} \%$ & $K_{\mathrm{Ni}}, \mathbf{w t} \%$ & $S_{a y}^{\delta}, \mu \mathrm{m}$ & $\Delta S^{\delta}, \%$ & $\begin{array}{c}K C V_{c p}, \\
\mathbf{J} / \mathbf{c m}^{2}\end{array}$ & $\triangle K C V, \%$ & B, $\%$ & $D, \%$ \\
\hline \multirow{5}{*}{$\begin{array}{l}\text { SAW+ } \\
\text { "ligature" }\end{array}$} & Basic version & Basic L & - & - & 394,0 & 96,7 & 50,1 & 21,2 & 62,3 & 37,7 \\
\hline & \multirow{2}{*}{\begin{tabular}{|c|} 
Height of the \\
ligature $2 \mathrm{~mm}$, \\
$\mathrm{K}_{\mathrm{CG}}=0,03 \mathrm{vol} \%$ \\
\end{tabular}} & $\mathrm{~L} / \mathrm{Ni}$ & - & 1,10 & 369,3 & 122,3 & 56,4 & 36,5 & 57,75 & 42,25 \\
\hline & & $\mathrm{L} / \mathrm{Ni}-\mathrm{TiC}$ & 0,05 & 0,19 & 286,8 & 133,9 & 39,5 & 82,3 & 75,36 & 24,64 \\
\hline & \multirow{2}{*}{$\begin{array}{l}\text { Height of the } \\
\text { ligature } 3 \mathrm{~mm} \text {, } \\
\mathrm{K}_{\mathrm{CG}}=0,04 \mathrm{vol} . \%\end{array}$} & $\mathrm{~L} / \mathrm{Ni}$ & - & 1,56 & 350,7 & 100,4 & 53,6 & 34,5 & 57,68 & 42,32 \\
\hline & & L/Ni-TiC & 0,16 & 0,57 & 313,9 & 89,8 & 43,5 & 57,5 & 75,32 & 24,68 \\
\hline \multirow[t]{5}{*}{$\begin{array}{l}\text { SAW + S } \\
\text { HA }\end{array}$} & Basic version & $\begin{array}{l}\text { Basic } \\
\text { SHA } \\
\end{array}$ & - & - & 100,00 & 120,00 & 58,6 & 49 & 62,3 & 37,7 \\
\hline & \multirow[b]{2}{*}{ Run «A» } & PP-P/Ni & - & 0,1 & 75,00 & 101,00 & 65,7 & 58 & 51,2 & 48,8 \\
\hline & & $\begin{array}{c}\mathrm{PP}-\mathrm{P} / \mathrm{Ni}- \\
\mathrm{TiC}\end{array}$ & 0,03 & 0,07 & 65,00 & 73,09 & 50,50 & 20 & 48,2 & 51,8 \\
\hline & \multirow[b]{2}{*}{ Run «B» } & PP-P/Ni & - & 0,23 & 100,00 & 100,00 & 71,8 & 45 & 49,5 & 50,5 \\
\hline & & $\begin{array}{c}\mathrm{PP}-\mathrm{P} / \mathrm{Ni}- \\
\mathrm{TiC}\end{array}$ & 0,07 & 0,16 & 66,16 & 39,31 & 80,00 & 56 & 43,4 & 56,6 \\
\hline $\begin{array}{l}\text { Note: } \\
\text { SAW + } \\
\text { SAW + } \\
\mathrm{K}_{\mathrm{CG}} \mathrm{V}_{\mathrm{CG}} \\
\mathrm{K}_{\mathrm{n}}-\mathrm{ma} \\
\mathrm{K}_{\mathrm{Ni}}-\mathrm{m} \\
\mathrm{S}_{\mathrm{av}}-\mathrm{a} \\
\Delta \mathrm{S}_{\mathrm{d}}-\mathrm{re} \\
\mathrm{KCV} \mathrm{V}_{\mathrm{cp}} \\
\Delta \mathrm{KCV}- \\
\mathrm{B}-\text { perc } \\
\mathrm{D}-\text { perc }\end{array}$ & $\begin{array}{l}\text { "ligature" - t } \\
\text { SHA - o ingle } \\
\text { volume fill fa } \\
\text { ass coefficient } \\
\text { ass coefficient } \\
\text { verage width o } \\
\text { elative spread } \\
\text { - average valu } \\
\text { - relative sprea } \\
\text { centage of britt } \\
\text { centage of duct }\end{array}$ & $\begin{array}{l}\text { wo-arc SA } \\
\text {-arc SAW } \\
\text { ctor of "lis } \\
\text { of nanosiz } \\
\text { of nickel } \\
\mathrm{f} \text { the weld } \\
\mathrm{n} \text { values o } \\
\mathrm{e} \text { of the } \mathrm{w} \\
\text { ad in value } \\
\text { tle constit } \\
\text { tile constit }\end{array}$ & $\begin{array}{l}\text { W with a } \\
\text { I with SH } \\
\text { gature", v } \\
\text { ed particl } \\
\text { introduct } \\
\text { I metal pri } \\
\text { f the wel } \\
\text { eld metal } \\
\text { es of the v } \\
\text { uent in the }\end{array}$ & $\begin{array}{l}\text { pre-laid ' } \\
\text { A; } \\
\text { ol .\%; } \\
\text { les introdu } \\
\text { ion, wt } \% \text {; } \\
\text { imary crys } \\
\text { d metal pr } \\
\text { impact to } \\
\text { veld metal } \\
\text { e fracture, } \\
\text { e fracture }\end{array}$ & $\begin{array}{l}\text { "ligature' } \\
\text { action, w1 } \\
\text { stals, } \mu \mathrm{m} \\
\text { rimary cr } \\
\text { ughness, } \\
1 \text { impact } \\
\% \text {; } \\
\% \text {. }\end{array}$ & $\begin{array}{l}\text { ystals wi } \\
\mathrm{J} / \mathrm{cm}^{2} \text {; } \\
\text { oughnes }\end{array}$ & $\begin{array}{l}\text { th, } \% \text {; } \\
\% \text {; }\end{array}$ & & & \\
\hline
\end{tabular}

After the welded joints were made, samples were cut from them to prepare the sections to study the structure of the weld metal. Samples of type X i according to [13] were also prepared for testing the toughness of weld metal at a temperature of minus $20^{\circ} \mathrm{C}$. After testing, the fracture surface was subjected to fractographic analysis.

\section{Result and discussion}

The macrostructure of a weld metal made using a ligature has a pronounced columnar structure and is a ferritic-pearlite mixture. Inside the columnar crystals, ferritic-pearlitic sections are observed, when the ferrite component of different dispersity predominates at the periphery. The use of nanosized particles does not change the morphology of the structural components.

When titanium carbide is introduced in the "ligature" composition, the average width of the primary crystals decreases, but it does not exceed 30\% (Table 3 ). In addition, the introduction of nanoscale titanium carbide particles in the "ligature" composition leads to a significant dispersion of the widths of the primary crystals, which can adversely affect the stability of mechanical properties.

In the welded joints with the use of DGP compounds defects in the form of pores and slag inclusions are not detected. The weld metal structure of welded joints can be characterized as a columnar dendritic, characteristic for a welded metal, welded under a flux in one pass.

The microstructure of the weld metal is ferrite and perlite, at high magnifications the structure of bainite is visible. The grains of ferrite are of a comminuted form, with a high 
degree of grain size nonhomogeneity. Perlite has a finely dispersed structure, and cementite is fragmentarily located along the boundaries of ferrite grains. Larger ferritic grains are located on the boundaries of columnar crystals. In the remaining volume, ferrite is smaller, with a high asymmetry of linear dimensions. Changes in the structure of columnar crystals do not significantly depend on the use of an additional additive.

The use of an additional hot additive results in a decrease in the width of the columnar crystals (Figure 3). The use of PP-P/Ni flux cored wire as an additive leads to a decrease in the average dimensions, structural components of the weld metal by $20-25 \%$, depending on the feed rate, which is associated with the appearance of an additional heat drain (Table 3 ).

The use of powder wires containing nanoscale particles leads to an orderly structure of the cast weld metal (a decrease in the spread of columnar crystal widths). In addition, the use of such powder wires leads to a reduction in the width of the columnar crystals with respect to both the base sample and the weld metal made using the PP-P/Ni flux cored wire. Thus, the use of powdered wires containing nano-sized particles of titanium carbide leads to a decrease in the average value of the width of columnar crystals by almost 2 times (by $40-50 \%$ ) compared to the base version, and by $20 \%$ compared to the application of the fluxwire PP-P/Ni. The spread of the values of the average crystal width is also reduced by $30 \ldots 45 \%$ in comparison with the application of the PP-P/Ni powder wire as a filler.

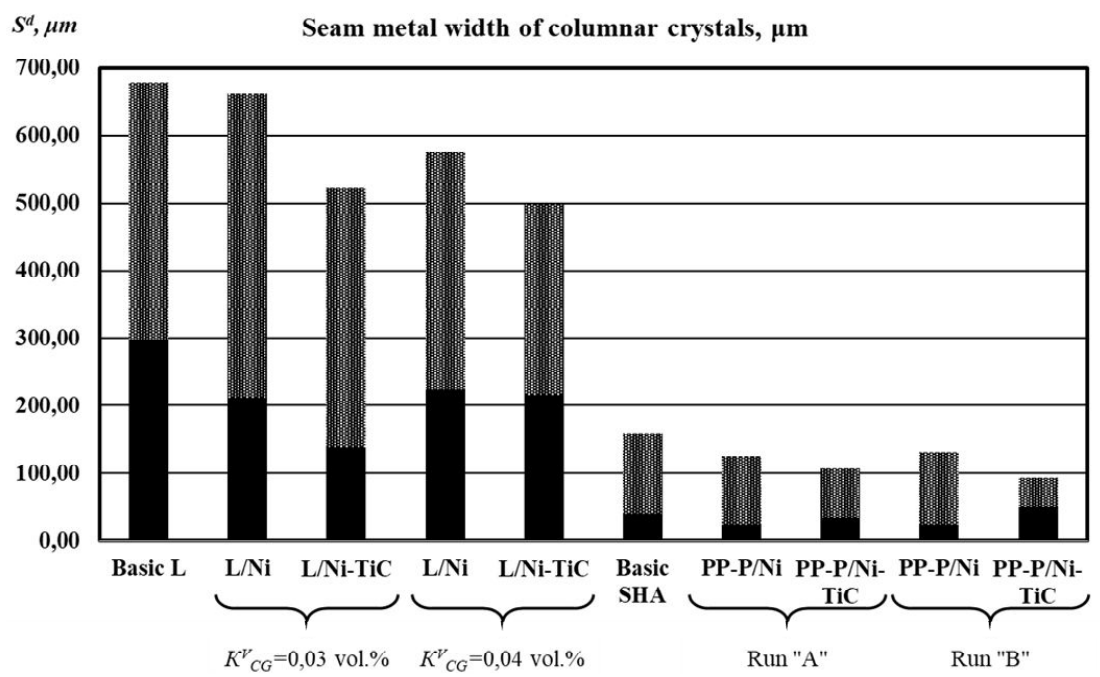

Fig. 2. Influence of composition and scheme of introduction of filler material on the width of columnar crystals of weld metal $\left(S^{d}\right)$. The designations in the figure correspond to those in Table 3 :

- minimum of width of the weld metal primary crystals, $\mu \mathrm{m}$;

- dispersion of width of the weld metal primary crystals, $\mu \mathrm{m}$.

Analysis of the results obtained after impact tests showed that the introduction of nickel powder $(\mathrm{L} / \mathrm{Ni})$ into the melt of the weld pool in a total amount of $1.10-1.56 \mathrm{wt} \%$ leads to an insignificant increase in the average value of the toughness of the weld metal: by 13 and $7 \%$, respectively, compared with the base version (Figure 4, Table 3). In this case, there is a decrease in the stability of its values. The slight influence of nickel on the toughness of the weld metal is explained by the high content of manganese in the weld metal, which agrees with the work [14]. 


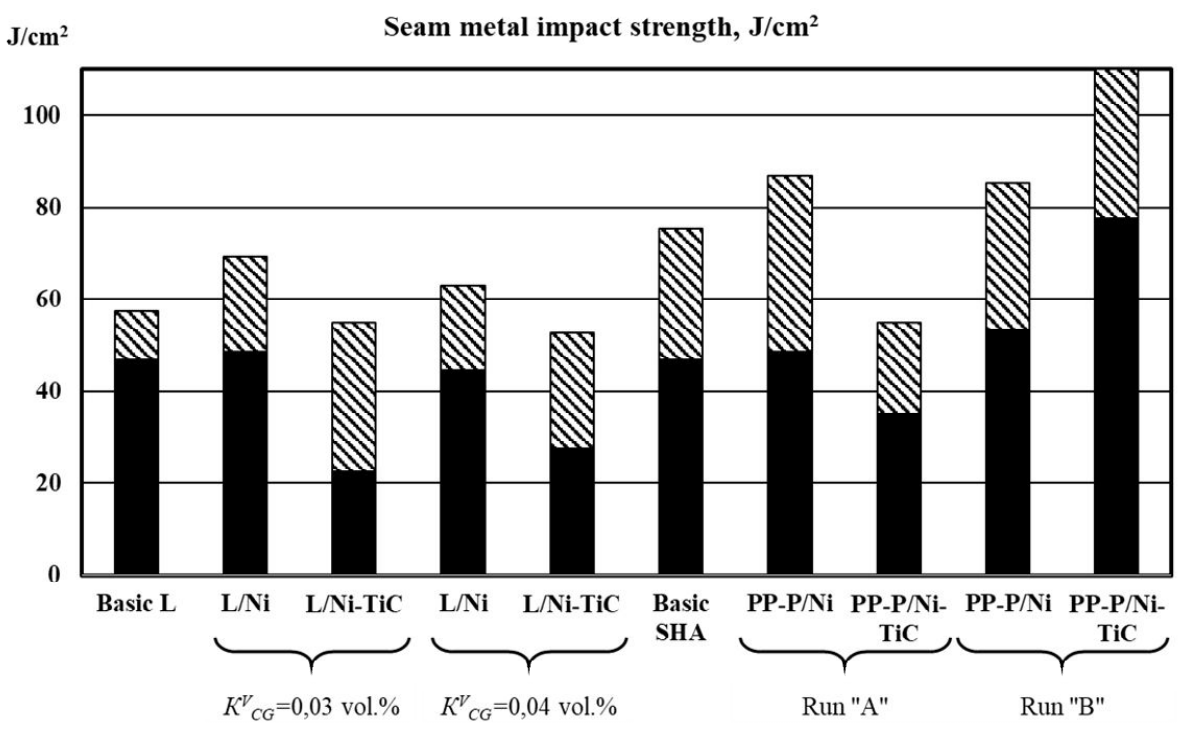

Fig. 3. Test results for impact strength at a temperature of minus $20^{\circ} \mathrm{C}$. The designations in the figure correspond to the notations in Table 3 :

$\mathbf{N}-$ minimum of impact toughness, $\mathrm{J} / \mathrm{cm} 2$;

The impact strength of the weld metal made with the L/Ni-TiC "ligature" was lower (by $12 \ldots 13 \%$ depending on the amount of additive added) of the mean values of the base version (Figure 4). In this case, there is an increase in the spread of the values of the impact strength. Also, nanoscale titanium carbide particles neutralize the positive effect of nickel on the toughness of the weld metal.

The weld metal, made using the basic technology for the SHA scheme, provides impact strength values from $40 \mathrm{~J} / \mathrm{cm}^{2}$ to $69 \mathrm{~J} / \mathrm{cm}^{2}$ at an average value of $58.6 \mathrm{~J} / \mathrm{cm}^{2}$. Thus, the spread of the impact strength values was more than $50 \%$.

The use of PP-P/Ni flux cored wire as an additional filler material results in a certain increase in the toughness of the weld metal: by $10 \%$ (with a $16 \%$ contribution of the filler wire in the weld metal) and by $20 \%$ (with the participation of the filler wire in the weld metal $41 \%$ ), which is due to the dispersion of the weld metal structure when using a filler wire.

The use of a PP-P/Ni-TiC flux-cored wire with a $16 \%$ weld share in the weld metal results in a $23 \%$ reduction in the toughness of the weld metal compared to the weld metal weld strength made using a PP-P/Ni flux-cored wire. An increase in the share of PP-P / Ni$\mathrm{TiC}$ flux cored wire in the weld metal to $41 \%$ leads to an increase in the average values of the toughness of the weld metal by $12 \%$ compared to the welded joint made with the use of PP-P/Ni flux cored wire.

Thus, the use of PP-P/Ni-TiC powder wires makes it possible to increase the average value of the toughness of weld metal from $58.6 \mathrm{~J} / \mathrm{cm}^{2}$ to $80 \mathrm{~J} / \mathrm{cm}^{2}$.

The fractographic analysis of the fractures included the analysis of the ratio of the brittle and viscous component (Table 3 ) according to $[15,16]$. Analysis of the results shows a decrease in the proportion of the viscous component when using the L Ni-TiC "ligature".

The use of a flux-cored wire with titanium carbide makes it possible to increase the percentage of the viscous component in the fracture by more than $50 \%$. The data obtained indicate an increase in the viscosity of the weld metal when nanodimensional titanium carbide particles are introduced into it. 


\section{Findings}

1. The prospects of modifying the weld metal of welded joints with a nano-sized particle of titanium carbide are shown by the scheme of their introduction into the tail part of a welding pool with the aid of a filler wire.

2. The introduction of nanoscale titanium carbide particles into the weld pool allows the structure of the weld metal to be dispersed. In this case, the greatest effect is achieved by introducing particles into the tail part of the weld pool by means of an additional filler wire.

3. The introduction of titanium carbide into the melt of the weld pool in the "ligature" leads to a decrease in the average values of the toughness of the weld metal: by $12 \%$ with the introduction of 0.05 mass $\%$ of the compound and by $13 \%$ when 0.16 mass $\%$ is introduced. In this case, an increase in the spread of the values of the impact strength is observed. At the same time, the introduction of titanium carbide contributes to the modification of the weld metal structure: the average width of the primary crystals decreases by at least $30 \%$.

4. The introduction of nano-sized titanium carbide particles in the filler filler wire allows the average impact strength to increase by $36 \%$, while the relative spread of these values remains commensurate with the spread obtained when testing the weld metal without the use of nanoscale particles.

The work was carried out with financial support of applied research by the Ministry of Education and Science of the Russian Federation (Agreement No. 14.578.21.0216 on granting a subsidy of September 28, 2016, the unique identifier of the RFIDF RFMEFI57816X0216).

\section{References}

1. RD-25.160.10-KTN-015-15 Trunk pipeline transport of oil and oil products. Part 1. Welding during the construction and repair of steel vertical tanks. Moscow (2015)

2. N.V. Kobernik, Svarka Diagnost, 5, 13 (2015)

3. A.S. Pankratov, Modifitsirovaniye metalla shva nanorazmernymi chastitsami karbida vol'frama $i$ nitrida titana pri svarke pod flyusom nizkouglerodistykh nizkolegirovannykh staley [Weld metal modification by tungsten carbides and titanium nitride nanosized particles in flux welding of the low-carbon low alloy steel]. Extended abstract of candidate's thesis. Moscow [in Russian] (2017)

4. N. P. Aleshin, HEM, 52, 5, 440 (2018)

5. N.P. Aleshin, NiR, 12, 12, 397 (2017)

6. A. A. Linnik, Razrabotka tekhnologicheskikh priyemov modifitsirovaniya metalla shva nanorazmernymi chastitsai s primeneniyem poroshkovykh provolok pri svarke pod flyusom [Technological methods development of the weld metal modification by nanosized particles using flux-cored wires in flux welding]. Extended abstract of candidate's thesis. Moscow [in Russian] (2017)

7. GOST 9722-97. Poroshok nikel'a. Tekhnicheskie uslovia. [The powder is nickel. Technical conditions.]

8. GOST 380-2005. Stal' uglerodistay obiknovennogo kachesta [Carbon steel, ordinary quality]

9. GOST 8713-79. Svarka pod flusom. Soedinenia svarnie. Osnovnie tipi, konstruktivnie elementi $i$ razmeri. [Flux welding. Welded joints. Math types design elements and dimensions] 
10. A.V. Samokhin, PCPP, 33, 3, 605 (2013)

11. A.V. Samokhin, Him. Vis. Ener., 50, 6, 461 (2016)

12. M.A. Sinayskiy, Ross. Nanotech., 11, 11-12, 110 (2016)

13. GOST 6996-66. Svarnie soedinenia. Metodi orredelenia mekhanicheskih svoistv. [Welded joints. Methods for determining mechanical properties.]

14. Z. Zhang, WR, 5, 183 (1997)

15. GOST 30456-97. Metalloprodukcia. Prokat listovoi i trubi stal'nie. Metodi ispitania na udarniy izgib. [Metal production. Rolled steel and tubes. Methods of blow bending tests.]

16. GOST R ISO 148-1-2013. Materiali metallicheskie. Ispitania na udarni izgib na maytnikovom kopre po Charpy. Chast' 1: Metod ispitaniy. [Metallic materials - Charpy pendulum impact test - Part 1: Test method.] 